Conference Program Planning-San Francisco, 1987: Monday, January 20, 2:00-4:00 p.m.

Nominating: Monday, January 20, 2:00-4:00 p.m.*

Section Review: Sunday, January 19, 8:30-11:00 a.m.

Standards Review: Saturday, January 18, 4:30-5:30 p.m.; Monday, January 20, 2:00-4:00 p.m.

Standards Review-Hearing: Sunday, January 19, 2:00-4:00 p.m.

\section{Western European Specialists Section}

Executive: Saturday, January 18, 4:30-5:30 p.m.; Tuesday, January 21, 8:30-11:00 a.m.

Classical, Medieval and Renaissance Discussion Group: Sunday, January 19, 2:00-4:00 p.m.
Conference Program Planning-New York, 1986: Monday, January 20, 8:00-9:00 a.m.

Conference Program Planning-San Francisco, 1987: Sunday, January 19, 9:30-11:00 a.m.

Discussion Group: Monday, January 20, 9:30-11:00 a.m.

Feasibility of a European Conference: Sunday, January 19, 8:00-9:00 a.m.

Nijhoff International Study Grant Jury: Saturday, January 19, 8:00-10:00 a.m.*

Nominating: Sunday, January 19, 8:00-9:00 a.m.*

Publications: Saturday, January 18, 2:00-4:00 p.m.

Research and Planning: Monday, January 20, 2:00-4:00 p.m.

\title{
ACRL candidates, 1986 elections
}

\section{Who's who on the Spring ballots.}

$\mathbf{T}_{\mathrm{b}}$ includes their title, institution, and institutional address.

\section{Vice-President/President-Elect}

Bob Carmack, Director, Hill Library, University of Wisconsin, Superior, WI 54880; Joanne R. Euster, Library Director, San Francisco State University, San Francisco, CA 94132.

\section{Board of Directors}

Councilor: Joseph Boissé, University Librarian, University of California, Santa Barbara, CA 93106; Thomas Kirk, College Librarian, Berea College, Berea, KY 40404.

Director-at-Large: Melvin R. George, Director of Libraries, Oregon State University, Corvallis, OR 97331; Joan Gotwals, Associate Director, University of Pennsylvania Libraries, Philadelphia, PA 19104.

\section{Anthropology and Sociology Section (ANSS)}

Vice-Chair/Chair-Elect: Chris D. Ferguson, Social Sciences Bibliographer, University Library, University of California, Irvine, CA 92713.

\section{Art Section (ARTS)}

Vice-Chair/Chair Elect: Nancy Allen, Assistant Director for Public Services, Wayne State University, Detroit, MI 48202.

\section{Asian and African Section (AAS)}

Vice-Chair/Chair-Elect: Jordan M. Scepanski, Director, University Library, California State University, Long Beach, CA 90840.

Member-at-Large: Linda Woo, Serials Division, University of Washington Library, Seattle, WA 98195; Ann L. Wood, Reference Librarian, Goodell Library, University of Massachusetts, Amherst, MA 01003. 


\section{Bibliographic Instruction Section (BIS)}

Vice-Chair/Chair-Elect: Barbara J. Wittkopf, Bibliographic Instruction Coordinator, Department of Reference and Bibliography, University of Florida Library, Gainesville, FL 32611; Laurene E. Zaporozhetz, Chair of Information Services, Bowling Green State University Library, Bowling Green, OH 43403.

Secretary: Esther Grassian, Reference Librarian, College Library, University of California, Los Angeles, CA 90024; Betsy Wilson, Assistant Undergraduate Librarian, University of Illinois at Urbana-Champaign, Urbana, IL 61801.

Member-at-Large: Patricia D. Arnott, Coordinator of Bibliographic Instruction, University of Delaware Library, Newark, DE 19717; Bonnie Gratch, User Education Coordinator, Jerome Library, Bowling Green State University, Bowling Green, OH 43403.

\section{College Libraries Section (CLS)}

Vice-Chair/Chair-Elect: George R. Parks, University Librarian, Colgate University, Hamilton, NY 13346; Richard Hume Werking, Director of Libraries, Trinity University, San Antonio, TX 78284 .

Secretary: Mignon Adams, Coordinator of Information Services, Penfield Library, SUNY/Oswego, Oswego, NY 13126; Laurene Lozoski, Automated Services Librarian, Bertrand Library, Bucknell University, Lewisburg, PA 17837.

\section{Community and Junior College Libraries Section (CJCLS)}

Vice-Chair/Chair-Elect: Eileen Dubin, Director of Library Services, Willaim Rainey Harper College, Palatine, IL 60067; Colette A. Wagner, LaGuardia Community College Library, Long Island City, NY 11101.

Secretary: Laura D. Fury, Library Director, Kent State University, Ashtabula Campus, Ashtabula, OH 44004; Shirley A. Lowman, Library Technical Services Director, Maricopa Community Colleges, Phoenix, AZ 85006.

\section{Education and Behavioral Sciences Section (EBSS)}

Vice-Chair/Chair-Elect: Ray Gerke, Assistant Librarian, Wessell Library, Tufts University, Medford, MA 02155; Marianna Markowitz, Education Librarian, University of Wisconsin, Milwaukee, WI 53201.

\section{Law and Political Science Section (LPSS)}

Vice-Chair/Chair-Elect: Carole A. Larson, Social Sciences Reference Librarian, University of Nebraska, Omaha, NE 68182; Natalie Schatz, Director, Edwin Ginn Library, Fletcher School of Law and Diplomacy, Tufts University, Medford,

\section{MA 02155 .}

Member-at-Large: Kate E. Adams, Subject Specialist, University Libraries, University of Nebraska, Lincoln, NE 68588; Stephen Atkins, Political Science Subject Specialist, University of Illinois Library, Urbana, IL 61801.

\section{Rare Books and Manuscripts Section (RBMS)}

Vice-Chair/Chair-Elect: Ann Gwyn, Assistant Library Director for Special Collections, Milton S. Eisenhower Library, Johns Hopkins University, Baltimore, MD 21210; Alice D. Schreyer, British and American Studies Librarian, Rutgers Universty Libraries, New Brunswick, NJ 08901.

Member-at-Large: James N. Green, Curator of Printed Books, Library Company of Philadelphia, Philadelphia, PA 19107; Nora J. Quinlan, Head, Special Collections, Norlin Library, University of Colorado, Boulder, CO 80309.

\section{Science and Technology Section (STS)}

Vice-Chair/Chair-Elect: Martin Kesselman, Science Librarian, Elmer Holmes Bobst Library, New York University, New York, NY 10012; Jacquelyn M. Morris, Associate Dean of Libraries, University of the Pacific, Stockton, CA 95211.

Secretary: Evelyn P. Fancher, Director of Libraries, Tennessee State University, Nashville, TN 37203; Antoinette P. Powell, Agriculture Library, University of Kentucky, Lexington, KY 40546.

\section{Slavic and East European Section (SEES)}

Vice-Chair/Chair-Elect: Michaela Harnick, Slavic Cataloger, Columbia University Libraries, New York, NY 10025; Cheryl A. Kern-Simirenko, Slavic and Women's Studies Librarian, Syracuse University, Syracuse, NY 13210.

Member-at-Large: Robert A. Karlowich, Associate Professor, Graduate School of Library and Information Science, Pratt Institute, Brooklyn, NY 11205; Viveca Seymour, Copy Cataloger, Green Library, Stanford University, Stanford, CA 94305.

\section{University Libraries Section (ULS)}

Vice-Chair/Chair-Elect: Barry B. Baker, Assistant Director for Technical Services, University of Georgia Libraries, Athens, GA 30602; Ferne B. Hyman, Assistant University Librarian for Collection Management, Fondren Library, Rice University, Houston, TX 77251.

\section{Western European Specialists Section (WESS)}

Vice-Chair/Chair-Elect: John R. Kaiser, Coordinator for Collection Development, Pattee Library, Pennsylvania State University, University Park, PA 16802; Assunta S. Pisani, Administrative Head, Collection Development Department, Harvard College Library, Cambridge, MA 02138.

Secretary: Richard D. Hacken, European Stud- 
ies Bibliographer, Harold B. Lee Library, Brigham Young University, Provo, UT 84602; Thomas D. Kilton, Assistant Modern Languages and Linguistics Librarian, University of Illinois, Urbana, IL 61801 .

Member-at-Large: Helga Borck, Assistant for
Resources, Collection Management \& Development Division, New York Public Library, New York, NY 10018; Barbara L. Walden, History Bibliographer, University of Minnesota Libraries, Minneapolis, MN 55455.

\title{
Managing a library publications program
}

\author{
By Jon Eldredge \\ Chief of Collections and Information Resources \\ University of New Mexico Medical Center Library
}

\section{The University of California, Irvine, wins the John Cotton Dana Award for its unique approach.}

$\mathbf{T}$ on a Special Award in the 1985 John Cotton Dana Library Public Relations Award contest for its unique and effective administration of a library publications program. The UC Library was one of 15 winners selected from the 173 entrants that participated in this year's contest. This annual contest has recognized the achievements of outstanding library public relations programs since its inception in 1946. Three university libraries and one community college library participated in the contest this year.

The UC Irvine Library provided clear evidence that it has been managing a superb publications program. This award-winning publications program has produced an exemplary assortment of brochures, guides, maps, bibliographies, and newsletters which all share a coordinated graphic arts format. A standard masthead scheme integrated into all items produced in this program, plus a combination of complementary colors have con- tributed to the pleasant visual effect produced by these publications. This unified design has been enhanced by the placement of these publications on handsome display racks located at service areas throughout the library system.

The most remarkable aspect of this program actually pertains to its method of administration. This large-scale publications program, capable of producing numerous printed items each year, has been managed by a small committee of professional librarians who work within the UC Irvine library. This committee has relied greatly upon the widespread participation and high level of cooperation of librarians within the Library to make this program a success. In the opinion of this judge the publications themselves must possess such a high degree of quality that the UC Irvine library entry would have won an award on the basis of this accomplishment alone. The program has acquired additional distinction though, on the merits of its unique method of administering with a committee. 